\title{
High abundance of small zoobenthos around biogenic structures in tidal sediments of the Wadden Sea
}

\author{
K. Reise \\ II. Zoologisches Institut der Universität Göttingen; \\ D-3400 Göttingen, Federal Republic of Germany \\ and \\ Biologische Anstalt Helgoland (Litoralstation); \\ D-2282 List/Sylt, Federal Republic of Germany
}

\begin{abstract}
On the tidal flats of the island of Sylt (eastern part of the North Sea) the quantity of micro- and meiofauna associated with shoots of seagrass (Zostera noltii), with infaunal bivalves (Macoma balthica), and with tubes and burrows of polychaetes (Pygospio elegans, Pectinaria koreni, Nereis diversicolor, Nereis virens, Arenicola marina) was found to add up to 5 to $33 \%$ of the overall abundance. These structures, taken together, account for 10 to $50 \%$ of the faunal abundance on an average tidal flat at Sylt. The quantitative effect of biogenic structures at the sediment surface (casts and funnels) is small compared to that of tubes and burrows penetrating the anaerobic subsurface layer. In providing stable oxic microenvironments these elite structures frequently bring together more individuals than occur in the entire reducing sediment below surface. Faunal composition of irrigated dwellings of large infauna is different from that of the oxic surface sediment. The common denominator of all elite structures of the subsurface is an oxic halo. Burrows without such a halo are unattractive. There is no evidence that owners of burrows prey on their smaller inmates.
\end{abstract}

\section{INTRODUCTION}

When digging up sediments out on the tidal flats in the Wadden Sea, a tricolor appears of brown in the surface layer $(0.2-2 \mathrm{~cm})$, next black $(10-15 \mathrm{~cm})$ and then grey at the bottom: Brown from iron hydroxides prevailing under oxic conditions, black and grey from iron sulfides and iron bisulfides indicating an anaerobic, reducing environment. In close-up, the black zone is pierced with numerous brownish or light grey tunnels, pockets and layers, all traces of macrofaunal activities below the surface. I studied the quantitative effects of such biogenic structures on small zoobenthos (microand meiofauna). The magnitude of these effects is such that they have to be considered in estimates on meiofaunal abundance; there is a strong preference of the entire subsurface fauna for the vicinity of irrigated burrows, and these observations give further support to the opinion that biotic factors play a role in determining the abundance and distribution in marine shallow water communities. 


\section{AREA AND METHODS}

All field investigations were carried out on the tidal flats in Königshafen, a bay on the island of Sylt (North Sea). The flats are sheltered, bare, relatively coarse grained (median $456 \mu \mathrm{m}$, sorting coefficient 1.5), with variable amounts of detritus, and populated by an abundant macrofauna (Wohlenberg, 1937; Reise, 1978). Tidal range is $1.7 \mathrm{~m}$, salinity remains close to $31 \% \mathrm{~S}$, temperatures in summer may reach $30^{\circ} \mathrm{C}$ in residual water during low tide, and about every other winter ice develops in the shallows.

Sampling was done in summer, at low tides and at day time, with tubes of 1 or $2 \mathrm{~cm}^{2}$ cross section. Out on the flats, cores were cut at intervals of 0.5 or $1 \mathrm{~cm}$ to study the vertical distribution of small fauna. When sampling burrows, these were put right in the center of the corer. To extract animals, 1 or $2 \mathrm{~cm}^{3}$ units of sediment were washed in a beaker with filtered sea water, shaken and decantated into a set of 8 to 12 petri dishes. These and the residual sand were searched for micro- and meiofauna under a stereomicroscope. Organisms were pipetted for counting purposes. Turbellaria, Gnathostomulida, Annelida and a few more were identified to species level. Only postnaupliar Copepoda are included. Counts on Ciliata refer to those $>200 \mu \mathrm{m}$ in length. In early investigations (1978) they have not been included at all. Zooflagellates were disregarded.

Because of the time consuming treatment of samples, replicates are few ( 3 to 14 ) and specifically those from burrows show large variances. This, and because non-randomness with singular peaks of exceptional high density in infaunal populations is common (Reise, 1979a), force me to confine statistical treatment to the conservative Wilcoxon twosample test, based on variance between ranks rather than on actual abundances. This test does not overrate singular exceptional values. Differences in rank distribution are taken as significant with $\mathrm{P}<0.05$.

\section{RESULTS}

\section{Zostera noltii Hornem.}

This small seagrass forms a dense cover from June to November on sheltered flats between 0 and $+0.5 \mathrm{~m} \mathrm{NN}$ at Sylt. The rhizome creeps 2 to $4 \mathrm{~cm}$ below the surface, and the roots create a meshwork 3 to $8 \mathrm{~cm}$ deep. From nodes, branches with 2 to 5 leaves or short generative shoots extend to the surface. $Z$. noltii occurs in patches.

In July 1980, sediment was oxic in the upper $5 \mathrm{~mm}$, and it was black below. With a corer of $2 \mathrm{~cm}^{2}$ cross section I sampled sediment immediately surrounding vertical shoots, and sediment just outside patches of seagrass.

Around seagrasses the abundance of meiofauna was higher (Table 1). Differences are significant at depth intervals $1-2 \mathrm{~cm}$ and $2-3 \mathrm{~cm}$ and for total cores. Variability between cores is increased by the presence of seagrass. Nematoda comprise $61 \%$ of the total and show the general pattern most clearly while other taxa show the same trend at lower levels of significance. The depth interval $1-3 \mathrm{~cm}$ of increased abundance implies that vertical branches and shoots cause the difference. By rotating in the tidal currents they break up the reducing sediment and allow an increased depth range of meiofauna. Roots have no effect. 
Table 1. Total fauna and Nematoda in $2 \mathrm{~cm}^{2}$-cores from patches of seagrass and from bare areas. Mean \pm s.d., $\mathrm{n}=5$; values significantly higher than controls are marked with an ${ }^{*}(\mathrm{P}<0.05$, Wilcoxon two-sample test); sandy tidal flat in Königshafen, July 1980

\begin{tabular}{|crrrrr|}
\hline $\begin{array}{c}\text { Depth in } \\
\text { sediment }(\mathrm{cm})\end{array}$ & $\begin{array}{c}\text { Total fauna } \\
\text { with seagrass }\end{array}$ & $\begin{array}{c}2 \mathrm{~cm}^{-2} \\
\text { no seagrass }\end{array}$ & $\begin{array}{c}\text { Nematoda } \\
\text { with seagrass }\end{array}$ & $\begin{array}{c}\mathrm{cm}^{-2} \\
\text { no seagrass }\end{array}$ \\
\hline $0-1$ & $307 \pm 109$ & $237 \pm 55$ & $145 \pm 81$ & $119 \pm 38$ \\
$1-2$ & $141 \pm 77^{*}$ & $31 \pm 24$ & $122 \pm 76^{*}$ & $27 \pm 14$ \\
$2-3$ & $74 \pm 75^{*}$ & $7 \pm 5$ & $70 \pm 2^{*}$ & $7 \pm 5$ \\
$3-4$ & $15 \pm 11$ & $4 \pm 3$ & $11 \pm 8$ & $3 \pm 2$ \\
$4-5$ & $3 \pm 5$ & $1 \pm 1$ & $2 \pm 4$ & $1 \pm 1$ \\
$0-5$ & $539 \pm 249^{*}$ & $282 \pm 49$ & $349 \pm 231^{*}$ & $153 \pm 38$ \\
\hline
\end{tabular}

\section{Macoma balthica (L.)}

This tellinid belongs to the most common of the bivalves in the Wadden Sea. The vertical position within sediment is a function of size, and adults usually stay at a depth of 3 to $8 \mathrm{~cm}$. The inhalent siphon extends to the surface while the exhalent siphon is much shorter and ends below. In a set of 6 samples taken from a sandy flat in July, one

Fig. 1. Vertical pattern of Nematoda and Turbellaria in a $2 \mathrm{~cm}^{2}$-core with Macoma balthica (12 mm length), and in 5 cores without this bivalve. Upper $4 \mathrm{~mm}$ of sediment brownish, below black; core length $5 \mathrm{~cm}$, divided into $0.5 \mathrm{~cm}$ intervals; individuals $\cdot \mathrm{cm}^{-3}$; sandy flat at mid tide in Königshafen, July 1980

\begin{tabular}{|c|c|c|c|c|}
\hline $\begin{array}{l}\text { Mean of } \\
5 \text { controls }\end{array}$ & $\begin{array}{l}\text { Macoma } \\
\text { sample }\end{array}$ & $\begin{array}{c}\text { Position of } \\
\text { Macoma balthica }\end{array}$ & $\begin{array}{l}\text { Macoma } \\
\text { sample }\end{array}$ & $\begin{array}{l}\text { Mean of } \\
5 \text { controls }\end{array}$ \\
\hline \multicolumn{2}{|c|}{ Nematoda } & & \multicolumn{2}{|c|}{ Turbellaria } \\
\hline 54 & 104 & \multirow[b]{3}{*}{ 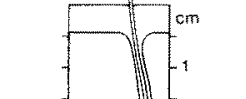 } & 2 & 5 \\
\hline 65 & 42 & & 1 & 1 \\
\hline 17 & 14 & & 0 & 0 \\
\hline 6 & 27 & \multirow{2}{*}{-2} & 0 & 0 \\
\hline 5 & 121 & & 3 & 0 \\
\hline 2 & 239 & $f^{2}$ & 8 & 0 \\
\hline 2 & 236 & $t^{3}$ & 10 & 0 \\
\hline 0 & 25 & \multirow[b]{3}{*}{1} & 3 & 0 \\
\hline 0 & 1 & & 0 & 0 \\
\hline 1 & 4 & & 0 & 0 \\
\hline
\end{tabular}

happened to include $M$. balthica. At the depth where the tellinid is positioned, Nematoda and Turbellaria increase far beyond control values (Fig. 1). In this core, Nematoda below $2 \mathrm{~cm}^{2}$ amount to 813 against $153 \pm 38$ in 5 controls. Turbellaria (Neoschizorhynchus parvorostro Ax \& Heller, Carenscoilia nov, spec., Retronectes nov. spec.) gather close to the bivalve in unusually high numbers. 


\section{Pygospio elegans Clap.}

This spionid polychaete lives in vertical tubes, 4 to $7 \mathrm{~cm}$ in length and $1 \mathrm{~mm}$ diameter. Frequently tubes are Y.shaped, with two chimneys at the sediment surface. Worms feed on deposits at the surface surrounding the tubes. The lower end of the tubes is open and worms deposit faeces down there. The tube is imigated by ciliary motion.

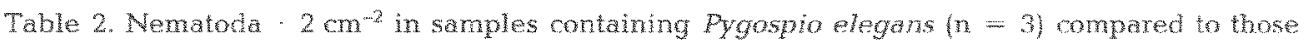

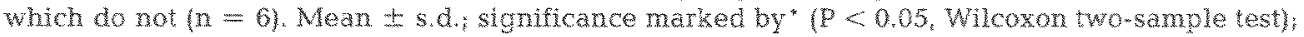
sendy flat at wid he in Konigshaten, June 1979

\begin{tabular}{|ccc|}
\hline $\begin{array}{c}\text { Depth in sediment } \\
\text { (mx) }\end{array}$ & $\begin{array}{c}\text { With } \\
\text { Pygospio elegans }\end{array}$ & No \\
$0-25$ & $182 \pm 17$ & $150 \pm 70$ \\
$25-50$ & $143 \pm 86^{*}$ & $40 \pm 30$ \\
$50-75$ & $117 \pm 110^{*}$ & $14 \pm 8$ \\
$75-100$ & $6 \pm 8$ & $3 \pm 3$ \\
$0-100$ & $449 \pm 174^{*}$ & $207 \pm 81$ \\
\hline
\end{tabular}

On a sandy flat in June 1979 , the mean density of adult $P$. elegans ( $>5 \mathrm{~mm}$ length) was $8 \cdot 100 \mathrm{~cm}^{-2}$. In a set of 10 samples $\left(2 \mathrm{~cm}^{2}, 10 \mathrm{~cm}\right.$ depth) 3 happened to include one adult $P$. elegans with the tube at the center. Comparison shows that Nematoda are about twice as abundant alongside these polychaete tubes (Table 2). The increase is due to significantly higher abundance at a depth of $25-75 \mathrm{~mm}$, which corresponds to the black sediment penetrated by the tube (Fig. 2). The overall quantitative effect of $P$. elegans on Nematoda of the flat is an increase of $19 \%$. Considering the reducing subsurface layer (>1 $\mathrm{cm}$ depth) alone, the increase is $35 \%$. Ciliata show the same trend but differences are not significant. To the total fana tubes add $6 \%$, and to the subsurface fanna $13 \%$.

One sample of this set contained a juvenile Corophium arenarium Crawt, living in a J-shaped tube down to $2,5 \mathrm{~cm}$ (Fig. 2). This sample was no control to the Pygospiosamples because of a high number of Nematoda close to the tube.

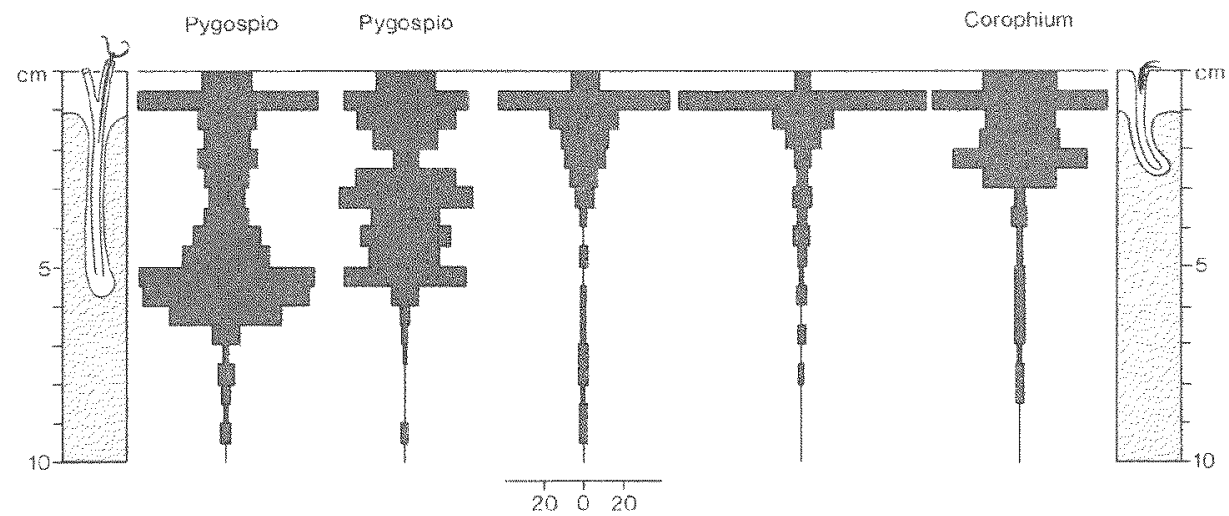

Fig. 2. Nematoda $2 \mathrm{~cm}^{-2}$ in 2 samples with Pygospio elegans, 2 with no macrofauna, and one with a juvenile Corophimm arenariwn. Invidivuals $\cdot \mathrm{cm}^{-3}$ in $0.5 \mathrm{~cm}$-intervals down to a depth of $10 \mathrm{~cm}$ sandy flat at mid tide in Konigshafen, June 1979 


\section{Pectinaria koreni Malmg.}

This terebellomorph polychaete lives head downwards in a conical tube made out of sand grains. A narrow chimney opens on to the sediment surface. At the lower opening of the cone the worm collects small particles with its tentacles. A respiratory current is drawn into the cone along the worm's ventral side, interrupted by brief and strong currents back to the surface along the dorsal side (Wilcke, 1952). The latter transports unwanted particles to the surface.

Nematoda

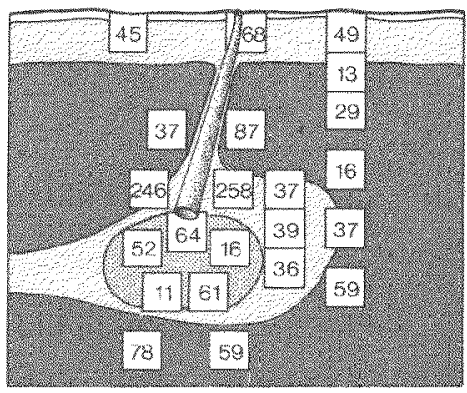

Michowhamus aberrans

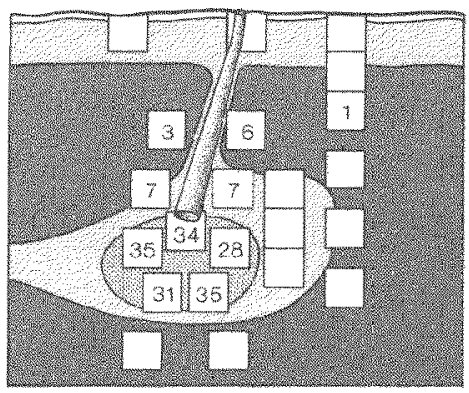

Gilate

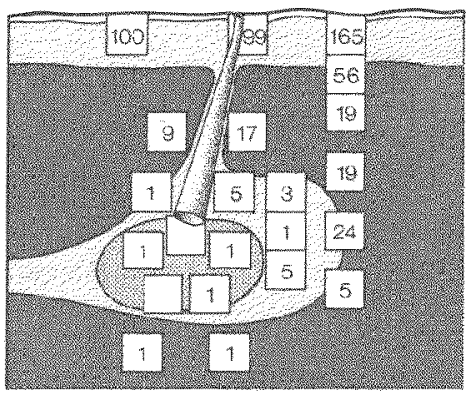

Tubiticidae

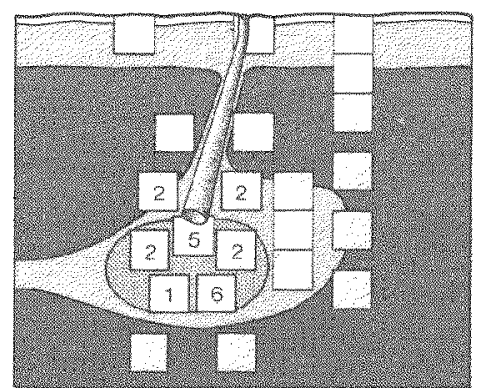

Fig. 3. Small zoobenthos $\mathrm{cm}^{-3}$ in the vicinity of Pectinatra koreni (cone length $5 \mathrm{~cm}$ ). Squares indicate positions of con ${ }^{3}$ samples. A layer of serni-fluid mud $(1-2$ mm) covers the surface, the next 10-15 mm are grey and below the sediment is black. In front of cone, brownish halo with coarse materials, surrounded by light grey coloured sand, 2 samples at left and right at lower end of cone with brownish silty sediment; llat at low tide in Königshafen, August 1980

In front of the lower opening a halo of oxic sediment with abundant shell fragments and other coarse materials was observed. Immediately surrounding the lower end of the cone, fine and sily materials were accumulated. In 1980 onemyear old $p$. koreni (cone length $5-7 \mathrm{~cm})$ populated the lower flats in Kongshafen $\left(10-60 \cdot \mathrm{m}^{-2}\right)$. At the site of investigation, sediment was oxic in the upper $1.5 \mathrm{~cm}$ and below it was black. At a depth of 5 to $7 \mathrm{~cm}$ I frequently encountered a layer rich in shell fragments, particularly in the vicinity of $p$. korent. Probably this layer is caused by its selective feeding. 
In March $1980 \mathrm{I}$ took a set of $1 \mathrm{~cm}^{3}$ samples from oxic halos in front of $P$. koreni $(\mathrm{n}=9)$ and in the black sediment nearby $(\mathrm{n}=8)$, both $6-7 \mathrm{~cm}$ below the surface. Abundance of Nematoda and small Annelida were significantly higher in halos: Nematoda $12 \pm 10$ versus $2 \pm 3$, Annelida $4 \pm 4$ versus none. Other taxa were present with few individuals only.

In August 1980 I mapped the distribution of small benthic fauna in the vicinity of $P$. koreni with a set of 22 samples of $1 \mathrm{~cm}^{3}$ each (Fig. 3). Abundance of Nematoda was not particularly high within the oxic region in front of the cone but the silty sediment surrounding the lower end of the cone contained exceptional densities. Ciliata were few in the halo with a tendency to increase towards the black region. The small polychaete Microphthalmus aberrans (Webster \& Benedict) gathers in spectacular numbers within the halo right in front of the cone. A less pronounced aggregation is formed by the Tubificidae (Edukemius benedii [d'Udekem] and Tubificoides pseudogaster [Dahl]). A few Copepoda, Ostracoda, Gastrotricha and Turbellaria were also encountered in the halo but not in the black sediment nearby.

\section{Nereis diversicolor O. F. Müller}

This nereid polychaete lives in a branched burrow, young ones with one opening, and older worms with two or more openings at the sediment surface where feeding takes place. Usually the burrows consist of a main vertical shaft extending to a depth of 15 to $20 \mathrm{~cm}$ on the flat investigated. Some of these are blind ends, others bend upwards again

Table 3. Small zoobenthos $\mathrm{cm}^{-3}$ around burrows of Nereis diversicolor, $2-16 \mathrm{~cm}$ below sediment surface $(n=14)$, away from burrows at same depth $(n=14)$, and from oxic sediment surface $(n=4)$. Mean \pm s.d.; all taxa are more abundant around burrows than controls $(P<0.05$, Wilcoxon two-sample test); sandy tidal flat in front of the harbour laboratory List, August 1978

\begin{tabular}{|lrcc|}
\hline Taxa & $\begin{array}{c}\text { Burrows at } \\
\text { 2-16 cm depth }\end{array}$ & $\begin{array}{c}\text { Controls at } \\
2-16 \mathrm{~cm} \text { depth }\end{array}$ & $\begin{array}{c}\text { Surface layer } \\
0-2 \mathrm{~cm} \text { depth }\end{array}$ \\
\hline Nematoda & $73.9 \pm 63.7$ & $8.3 \pm 10.1$ & $122.3 \pm 64.1$ \\
Gnathostomulida & $0.9 \pm 2.1$ & 0.2 & 0 \\
Turbellaria & $3.2 \pm 3.6$ & 0.1 & $7.5 \pm 7.0$ \\
Oligochaeta & $0.6 \pm 0.8$ & 0.1 & $0.8 \pm 0.5$ \\
Copepoda & $16.0 \pm 20.3$ & $3.1 \pm 6.3$ & $19.5 \pm 15.9$ \\
Total fauna & $95.4 \pm 82.2$ & $12.3 \pm 13.4$ & $164.3 \pm 87.5$ \\
\hline
\end{tabular}

making a V-shaped burrow. Most branches occur in the upper $10 \mathrm{~cm}$. Some of them run horizontally just below the surface. The inner diameter of the shafts is $3-4 \mathrm{~mm}$. Burrows are lined with a darkish tapetum and are surrounded by a halo of oxic sediment (1-2 $\mathrm{mm}$ ). Some blind ends are filled with fecal pellets, and several branches seem to be abandoned or to be rarely in use. Worms irrigate their burrows with undulating body movements.

On a sandy flat in front of the harbour laboratory of the littoral station List, $N$. diversicolor occurs in high density $\left(1036 \cdot \mathrm{m}^{-2}\right.$ in September $1977,1076 \cdot \mathrm{m}^{-2}$ in June 1978). In August 1978, the upper $2 \mathrm{~cm}$ of sediment were oxic, below it turned grey or 
black. From several burrows I took $1 \mathrm{~cm}^{3}$ samples at various depths between $2-16 \mathrm{~cm}$ together with controls at least $5 \mathrm{~cm}$ apart from the nearest burrow. The abundance of meiofauna alongside burrows is several times higher than in the black sediment and similar to the fauna of the oxic surface layer (Table 3). Nematoda were particularly abundant near the blind ends with fecal pellets (up to $197 \cdot \mathrm{cm}^{-3}$ ), and Copepoda were most numerous in burrow regions below $10 \mathrm{~cm}$ depth: $2-10 \mathrm{~cm}$ with $4 \pm 3 \cdot \mathrm{cm}^{-3}, 10-16$ $\mathrm{cm}$ with $33 \pm 22 \cdot \mathrm{cm}^{-3}$. Assuming for $N$. diversicolor a density of $1000 \cdot \mathrm{m}^{-2}$ and an estimated burrow length of $20 \mathrm{~cm}$ within the reducing layer, abundance on this flat for small fauna with and without $N$. diversicolor can be calculated with the data given in table 3. Compared to the hypothetical situation without burrows, percentages of increase are: Copepoda 31 , Oligochaeta and the entire fauna 33 , Nematoda 36 , Turbellaria 38 , Gnathostomulida 50. Considering the subsurface fauna alone, individuals around burrows outnumber those within the entire reducing zone.

\section{Nereis virens Sars}

This large polychaete lives in a complex burrow, essentially composed of U-shaped elements with several openings at the sediment surface. Most branches are in the upper $10 \mathrm{~cm}$. Burrows have an inner diameter of $5 \mathrm{~mm}$, are lined with a tapetum and are surrounded by a narrow zone of oxic sediment and a wider halo of light grey sediment, varying in extent. In some of the upper branches, $N$. virens has pulled down algae (Cladophora spec. and Enteromorpha spec.).

On a flat at low tide level of silty-sand sediment, I found a population of one-year old $N$. virens with $90 \cdot \mathrm{m}^{-2}$ (calculated from 18 samples of $100 \mathrm{~cm}^{2}$ each taken in August 1980). Three sediment cores of $100 \mathrm{~cm}^{2}$ were sliced to a depth of $18 \mathrm{~cm}$ and the total length of burrows was measured to $47 \mathrm{~cm}, 62 \mathrm{~cm}$ and $66 \mathrm{~cm}$. This amount to $58 \mathrm{~m} \cdot \mathrm{m}^{-2}$.

Burrows are populated by an abundant meiofauna (Table 4). While at the sediment surface the fauna is dominated by Gastrotricha (Turbanella cornuta Remane with up to $1150 \cdot \mathrm{cm}^{-3}$ ) and Ciliata, burrows are dominated by Nematoda (up to $519 \cdot \mathrm{cm}^{-3}$ ). Compared to controls from the black sediment 3 to $5 \mathrm{~cm}$ apart from burrows, all taxa

Table 4. Small zoobenthos $\cdot \mathrm{cm}^{-3}$ around burrows of Nereis virens, $9-10 \mathrm{~cm}$ below sediment surface $(\mathrm{n}=10)$, away from burrows at same depth $(\mathrm{n}=10)$, and from oxic sediment surface $(\mathrm{n}=6)$. Mean \pm s.d.; all taxa are more abundant at burrows than controls $(P<0.05$, Wilcoxon two-sample test); flat at low tide in Königshafen, August 1980

\begin{tabular}{|lcccc|}
\hline Taxa & $\begin{array}{c}\text { Burrows at } \\
9-10 \mathrm{~cm} \text { depth }\end{array}$ & $\begin{array}{c}\text { Controls at } \\
9-10 \mathrm{~cm} \text { depth }\end{array}$ & $\begin{array}{c}\text { Surface layer } \\
0-1 \mathrm{~cm} \text { depth }\end{array}$ \\
\hline Ciliata & $17 \pm 12$ & $1.1 \pm 1.4$ & $130 \pm 41$ \\
Gastrotricha & $3.3 \pm 4.4$ & 0 & $495 \pm 412$ \\
Nematoda & $346 \pm 110$ & $9 \pm 11$ & $54 \pm 8$ \\
Gnathostomulida & $3.4 \pm 3.7$ & 0.1 & 0.1 & $7.7 \pm 4.4$ \\
Turbellaria & $2.9 \pm 2.6$ & 0.1 & $1.3 \pm 1.4$ \\
Annelida & $0.8 \pm 1.0$ & 0 & $13.2 \pm 5.5$ \\
Copepoda & $2.6 \pm 2.0$ & 0 & $717 \pm 405$ \\
Total fauna & $379 \pm 124$ & $10 \pm 11$ & & \\
\hline
\end{tabular}


Table 5. Horizontal profile of contiguous $1 \mathrm{~cm}^{3}$-cubes through a burrow of Nereis virens at $8 \mathrm{~cm}$ below surface. The burrow is lined by a brownish halo merging into light grey coloured sand, the general sediment is dark grey or black. Detritus content increases from right to left. Individuals $\mathrm{cm}^{-3}$; flat at low tide in Königshafen, August 1980

\begin{tabular}{|lcccccc|}
\hline Taxa & black & dark grey & $\begin{array}{c}\text { Colour of sediment } \\
\text { brown halo }\end{array}$ & light grey & dark grey & dark grey \\
\hline Ciliata & 0 & 4 & 8 & 9 & 5 & 0 \\
Gastrotricha & 0 & 0 & 5 & 0 & 0 & 0 \\
Nematoda & 14 & 178 & 157 & 65 & 14 & 0 \\
Gnathostomulida & 0 & 2 & 1 & 3 & 1 & 0 \\
Turbellaria & 0 & 1 & 3 & 0 & 0 & 0 \\
Oligochaeta & 0 & 0 & 1 & 0 & 0 & 0 \\
Copepoda & 0 & 0 & 3 & 0 & 0 & 0 \\
\hline
\end{tabular}

were significantly more abundant at burrows. Fine scale analysis, carried out on a cross section of a burrow, shows that most meiofauna stays directly near the burrow but Ciliata, Nematoda and Gnathostomulida are found 1-2 cm apart as well (Table 5).

A rough calculation shows that $N$. virens burrows add $24 \%$ to the total abundance of small zoobenthos on that flat. Numbers of Nematoda are even raised by $94 \%$. In Gnathostomulida, numbers are twice as high with burrows. If the subsurface sediment is considered alone, there are more individuals bound to burrows than occur in the entire subsurface layer.

\section{Arenicola marina (L.)}

Lugworms live in U-shaped burrows which consist (1) of a temporary structure, starting with a funnel at the sediment surface which merges into a vertical head shaft. Here surface sediment slides downwards and gets ingested by the lugworm in a pocket region at the base of the burrow. (2) The worm itself stays in a horizontal gallery at 15-20 $\mathrm{cm}$ depth. (3) To defecate ingested sediment worms move upwards through a permanent tail shaft, and produce mounds of coiled castings right above at the surface. For respiration, lugworms pump water through the tail shaft down into the gallery.

A description of meiofauna found in different regions of the Arenicola-burrow has been given by Reise \& Ax (1979). Here some additions are presented. Nematoda prefer

Table 6. Meiofauna $10 \mathrm{~cm}^{-3}$ in normal subsurface sediment $(>1 \mathrm{~cm}$ depth) and around burrow structures generated by Arenicola marina. Mean \pm s.d. from 3 head shafts, 3 tail shafts and 5 pockets; sandy flat at mid tide in Königshafen, June/July 1978

\begin{tabular}{|lcrrrr|}
\hline Taxa & $\begin{array}{c}\text { Normal subsurface } \\
\text { sediment }\end{array}$ & head shaft & Burrow of Arenicola marina \\
& pocket & tail shaft \\
\hline Nematoda & $67 \pm 21$ & $417 \pm 285$ & $79 \pm 45$ & $395 \pm 40$ \\
Turbellaria & 1.5 & $15 \pm 14$ & $77 \pm 55$ & $23 \pm 9$ \\
Copepoda & 1.1 & $30 \pm 28$ & $110 \pm 130$ & $33 \pm 19$ \\
Total fauna & $74 \pm 21$ & $515 \pm 223$ & $395 \pm 130$ & $503 \pm 81$ \\
\hline
\end{tabular}


Table 7. Small zoobenthos $\mathrm{cm}^{-3}$ in normal surface sediment (0-1 $\mathrm{cm}$ depth) and where modified by Arenicola marina to funnels and casts. Mean \pm s.d., $\mathrm{n}=6$; $\mathrm{a}=$ without Archilopsis unipunctata, $\mathrm{b}=$ cockles on $25 \mathrm{~cm}^{2}+=$ significant preference, $-=$ significant avoidance $(\mathrm{P}<0.05$, Wilcoxon two-sample test); sandy flat at mid tide in Königshafen, July 1978

\begin{tabular}{|c|c|c|c|}
\hline Taxa & Flat surface & Funnel & Cast \\
\hline Turbellaria ${ }^{a}$ & $10.8 \pm 3.2^{+}$ & $4.2 \pm$ & $5.2 \pm 4.2$ \\
\hline Nematoda & $137 \pm 36^{+}$ & $48 \pm 27$ & $62 \pm 15$ \\
\hline Gastrotricha & $1.3 \pm 1.0^{+}$ & 0 & 0.2 \\
\hline Cerastoderma edule $(<4 \mathrm{~mm})^{\mathrm{b}}$ & $18.5 \pm 2.9^{+}$ & $8.2 \pm$ & $6.2 \pm 1.7$ \\
\hline Hydrobia ulvae & $18.0 \pm 4.7$ & $19.5 \pm 16.3$ & $2.3 \pm 1.4^{-}$ \\
\hline Total fauna & $302 \pm 69$ & $367 \pm 114$ & $137 \pm 33^{-}$ \\
\hline Copepoda & $110 \pm 43$ & $274 \pm 111^{+}$ & $43 \pm 26^{-}$ \\
\hline Annelida & $8.3 \pm 4.5$ & $10.0 \pm 9.1$ & $6.5 \pm 2.0$ \\
\hline Foraminifera & $0.6 \pm 0.9$ & $1.3 \pm$ & $3.8 \pm 3.1^{+}$ \\
\hline Archilopsis unipunctata & $1.8 \pm 2.2$ & $2.3 \pm$ & $6.5 \pm 4.0^{+}$ \\
\hline
\end{tabular}

the upper regions of the burrow while Copepoda and Turbellaria are most numerous in the pocket, and the latter in the lower tail shaft too (Fig. 4). Variability between burrows is high. Abundance of all small fauna is 5 to 7 times higher at burrows than in the normal subsurface sediment (Table 6).

At the sediment surface, funnels and casts differ in meiofaunal abundance from each other and from the flat surface (Table 7). Most Turbellaria, Nematoda, Gastrotricha and cockle spat stay away from casts and funnels, while the gastropod Hydrobia ulvae (Pennant) avoids casts only. When the tide is out, Copepoda aggregate in funnels which represent tiny lowtide ponds. They avoid casts too. Contrary to all others, Foraminifera and the turbellarian Archilopsis unipunctata (Fabr.) are most abundant within casts.

Generally, surface structures generated by the lugworm tend to decrease and burrows tend to increase abundance of small zoobenthos. Based on investigations carried out in June/July 1978 on a sandy flat at mid tide level, the overall quantitative effect of lugworm burrows is estimated. Abundance of $A$. marina was $43 \cdot \mathrm{m}^{-2}$. Areas of single casts and funnels cover approximately $7 \mathrm{~cm}^{2}$. Head shafts comprise $15 \mathrm{~cm}^{3}$, pockets $10 \mathrm{~cm}^{3}$, tail shafts $112 \mathrm{~cm}^{3}$. Taking the data on abundance from tables 6 and 7 , the net amount of change due to structures generated by $A$. marina is calculated (Table 8). Because the fauna of the surface layer dominates with about $70 \%$, the overall increase caused by $A$. marina is only $5 \%$. Considering the subsurface layer alone, the

Table 8. Percentages of decrease (-) and increase $(+)$ in small zoobenthos because of sediment structures generated by Arenicola marina on a sandy flat at mid tide in Königshafen, June/July 1978

\begin{tabular}{|lccc|}
\hline Taxa & Surface layer & Subsurface layer & Entire sediment \\
\hline Nematoda & -4 & +17 & +5 \\
Turbellaria & -2 & +68 & +9 \\
Copepoda & +3 & +136 & +5 \\
Total fauna & -1 & +22 & +5 \\
\hline
\end{tabular}



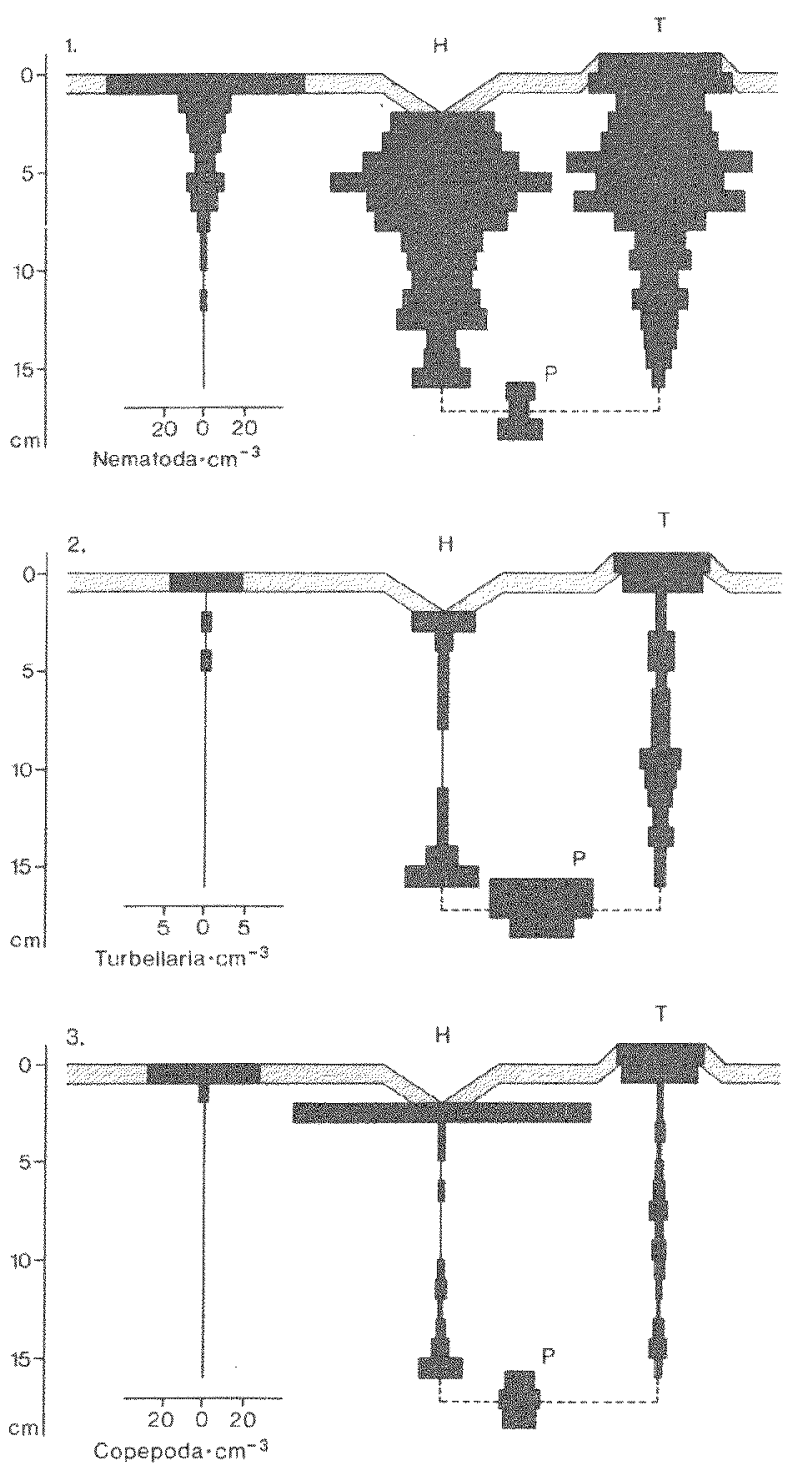

Fig, 1. Meiofauna $\mathrm{cm}^{-3}$ alongside head shaft (H), pocket (P) and tail shaft (T) of Arenicola-burrow and in normal sediment down to $16 \mathrm{~cm}$ below surlace. Means of 3 burrows and 3 controls; sandy flat at mid the in Kromgshafen, June/July 1978

effect of lugworms is quite remarkable in some taxa, and a $22 \%$ increase for the total fauna.

On another Arenicola-flat, quantitative investigations were camied out in June 1980 , with respect to Turbellaria and Gnathostomulida only. Here, an overall increase in aburdance due to Arenicola-burrows amounts to $10 \%$ in Turbellaria and $18 \%$ in Gnathostomulida. 


\section{DISCUSSION}

Why does small zoobenthos gather in high numbers around burrows and tubes of large species? There will be a variety of reasons for the various species; however, an oxic halo surrounding these structures when penetrating the reducing subsurface sediment is the common denominator of all of them. Crucial evidence is the indifference of micro- and meiofauna to burrows of Heteromastus filiformis (Clap.). This capitellid polychaete, although feeding on particles within reducing sediment at a depth of 10 to $15 \mathrm{~cm}$, does not irrigate its burrow. Instead, an elongated tail is kept in the oxic layer above to take up oxygen. These burrows are not lined by an oxic halo.

May we regard irrigated dwellings of large infaunal species simply as narrow protrusions of the oxic surface layer, inhabited by the same assemblage of small species? This is evidently not the case. Neither the quantitative ratios between major taxa nor the species composition is the same (see Reise \& Ax, 1979). In many physical aspects the burrow environment is different: high sediment stability, mucus lining of the burrow wall, no dislocating currents, stable temperatures, no light, etc. Aller \& Yingst (1978) described the specific biogeochemistry of an irrigated polychaete burrow, and found highest concentrations of metals, sulfides, ammonium, ATP, high rates of sulfate reduction and rapid decomposition in the burrow wall. The rapid change in sediment colour from brown over grey to black within small distance from the burrow implies a steep gradient from aerobic to anaerobic conditions, an ideal situation for an active microbial sulfur cycle. On retirement of the owner and irrigator of the burrow, the smaller inmates must be able to endure anaerobic conditions or move out quickly.

Do burrow owners take advantage of the small organisms attracted? Hylleberg (1975) proposed a concept of gardening in lugworms: in the pocket region of the burrow, irrigation enhances bacterial growth which attracts flagellates, ciliates and nematodes and this entire community serves as food to the lugworm. The concept is derived from investigations on Abarenicola pacifica Healy \& Wells, and probably does not apply to $A$. marina. Residence time of sediment in the head shaft is a few hours only (Rijken, 1979). High'numbers of ciliates, turbellarians and copepods in the pocket region are found in the coarse grained sand which accumulates below the head shaft because $A$. marina ingests small particles only. Hence these organisms are saved from getting swallowed.

Numbers of nematodes are high alongside burrows of Nereis virens and $N$. diversicolor. The latter is a predator on nematodes (Reise, 1979b) and most likely $N$. virens does the same. Burrows, however, are lined with a firm tapetum of mucus and most nematodes stay on the other side. I observed no signs of preying beyond the tapetum. On the other hand, in some branches feces are accumulated and in others pulled-down green algae decompose. This might be attempts at gardening (see also Woodin, 1977a).

What is the overall quantitative effect of biogenic structures on meiofauna of tidal flats? Surface structures generated by $A$. marina tend to decrease total abundance (in the order of $1 \%$ only). The same was observed for copepods where other polychaetes generate structures at the surface and with mounds of enteropneusts (Thistle 1979, 1980). Burrows of fiddler crabs are avoided by copepods while nematodes are attracted (Bell et. al., 1978). The vicinity of tube-caps of the polychaete Diopatra cuprea serves as a refuge to smaller polychaetes (Woodin, 1977b). Fecal cones of Molpadia oolitica (Pourt.) (Holothuroidea) provide a stable surface to small suspension feeders (Rhoads \& Young, 
1971). Effects of biogenic surface structures on small zoobenthos are a widespread phenomenon. However, the examples cited above suggest that positive and negative effects might be in balance.

This is quite different with burrows and tubes penetrating the anaerobic subsurface sediment. They constitute elite structures to the faunal assemblage because they tie up more than their spatial share of overall abundance. Dense assemblages of Nereis spp. double the total number of subsurface fauna and some taxa occur almost exclusively around burrows. On a sandy flat, where $A$. marina and $P$. elegans have been studied, their burrows add $22+13=35 \%$ to the subsurface fauna, for nematodes alone $17+35=52 \%$. Other taxa, like Copepoda and Gnathostomulida are doubled by Arenicola-burrows. Thus it appears that burrows and tubes contribute the major component to the subsurface zoobenthos.

When surface and subsurface fauna are taken together, biogenic structures have been found to account for 5 to $33 \%$ of total abundance. These percentages are derived from the single structures investigated but usually several occur together on the same flat. Thus, for an average tidal flat on the island of Sylt, the combined effect will account for 10 to $50 \%$. A sampling strategy, not paying special attention to biogenic elite structures will underestimate the abundance of meiofauna considerably.

Acknowledgements. I am grateful to Professor O. Kinne and the staff of the Biologische Anstalt Helgoland in List, who generously provided laboratory facilities and helped in many technical aspects. K. Kossmagk identified Tubificoides pseudogaster. Drawings were skillfully prepared by R. von Sivers. The Deutsche Forschungsgemeinschaft (DFG) funded this work ( $\operatorname{Re} 425)$.

\section{LITERATURE CITED}

Aller, R. C. \& Yingst, J. Y., 1978. Biogeochemistry of tubedwelling: a study of the sedentary polychaete Amphitrite ornata (Leidy). - J. mar. Res. 36, 201-254.

Bell, S. S., Watzin, M. C. \& Coull, B. C., 1978. Biogenic structure and its effect on the spatial heterogeneity of meiofauna in a salt marsh. - J. exp. mar. Biol. Ecol. 35, 99-107.

Hylleberg, J., 1975. Selective feeding by Abarenicola pacifica with notes on Abarenicola vagabunda and a concept of gardening in lugworms. - Ophelia 14, 113-137.

Reise, K., 1978. Experiments on epibenthic predation in the Wadden Sea. - Helgoländer wiss. Meeresunters. 31, 55-101.

Reise, K., 1979a. Spatial configurations generated by motile benthic polychaetes. - Helgoländer wiss. Meeresunters. 32, 55-72.

Reise, K., 1979b. Moderate predation on meiofauna by the macrobenthos of the Wadden Sea. Helgoländer wiss. Meeresunters. 32, 453-465.

Reise, K. \& Ax, P., 1979. A meiofaunal "thiobios" limited to the anaerobic sulfide system of marine sand does not exist. - Mar. Biol. 54, 225-237.

Rhoads, D. C. \& Young, D. K., 1971. Animal-sediment relations in Cape Cod Bay, Massachusetts. II. Reworking by Molpadia oolotica (Holothuroidea). - Mar, Biol. 11, 255-261.

Rijken, M., 1979. Food and food uptake in Arenicola marina. - Neth. J. Sea Res. 13,406-421.

Thistle, D., 1979. Deep-sea harpacticoid copepod diversity maintenance: the role of polychaetes.Mar. Biol. 52, 371-376.

Thistle, D., 1980. The response of a harpacticoid copepod community to a small-scale natural disturbance. - J. mar. Res. 38, 381-395.

Wilcke, D. E., 1952. Beobachtungen über den Bau und die Funktion des Röhren- und Kammersystems der Pectinaria koreni Malmgren. - Helgoländer wiss. Meeresunters. 4, 130-137.

Wohlenberg, E., 1937. Die Wattenmeer-Lebensgemeinschaften im Königshafen von Sylt. - Helgoländer wiss. Meeresunters. 1, 1-92. 
Woodin, S. A., 1977a. Algal "gardening" behavior by nereid polychaetes: Effects on soft-bottom community structure. - Mar. Biol. 44, 39-42.

Woodin, S. A., $1977 \mathrm{~b}$, Refuges, disturbance, and community structure: A marine soft-bottom example. - Ecology 59, 274-284. 